\title{
NATURAL HISTORY NOTE \\ Record of Great Woolly Horseshoe Bat (Rhinolophus luctus, Temmick 1834) in Northeast Bangladesh
}

\author{
Tanvir Ahmed ${ }^{1, *}$, Sabit Hasan ${ }^{1}$, Habibon Naher ${ }^{1}$, Sabir Bin Muzaffar ${ }^{2}$
}

${ }^{1}$ Department of Zoology, Jagannath University, Dhaka 1100, Bangladesh.

${ }^{2}$ Department of Biology, United Arab Emirates University, PO Box 17551, Al Ain, UAE

*Corresponding author:

shaikot2023jnu@gmail.com

DOI: https://doi.org/10.14709/

BarbJ.13.1.2020.08

Keywords: Chiroptera, distribution, Rhinolophus luctus, trifoliate group.

received: November, 11th 2019 accepted: April, 19th 2020

\begin{abstract}
Bangladeshi chiropteran fauna is poorly studied and there is a lack of complete inventories. A total of 39 species of bats have been reported to occur in the country. Great Woolly Horseshoe Bat Rhinolophus luctus, (Temmick 1834) has been expected to occur in northeast Bangladesh based on its presence in north-eastern India and adjoining areas. However, there had been no published report on the occurrence to date. We first report the occurrence of $R$. luctus in a northeastern forest of Bangladesh. A pair of $R$. luctus were spotted opportunistically and photographed on September 4, 2019 along the shoreline of a rocky stream in Patharia Hill Reserve Forest while surveying non-human primates. This forest is an important reservoir for several globally threatened species in northeast Bangladesh though the characterization of its biodiversity is yet incomplete. Further study into the regions faunal diversity may reveal additional species, particularly the bats. So, complete assessments of the conservation status of Bangladeshi bat fauna is urgently needed to implement effective conservation measures.
\end{abstract}

Inventories are critical tools to aid in resource planning and species conservation (Morrison et al. 2008). Even basic information on the distribution of species and habitats in an area can then help design management plans to protect or enhance conditions for desired species, whether they are threatened or endangered species or those valued for consumptive or non-consumptive reasons (Morrison et al. 2008). Regarding inadequate and incomplete inventories, opportunistic sightings can reveal not only presence but also provide realistic abundance estimation of illusive fauna like Felids while collecting data on other species (Borries \& Koenig 2014). Yet opportunistic sightings data has its flaws, including the lack of data on species absences and unequal sampling effort, though these data may still provide reliable information on the distribution of species and complement localized, hypothesis driven research (Okes \& O'Riain 2019). So, where possible opportunistic sightings data should be validated against traditional methods to determine their value for long term monitoring programs especially for the poorly studied taxa (Okes \& O’Riain 2019).

Bats are one of the most poorly studied mammal groups (Frick et al. 2019). Bats are often persecuted since they serve as reservoirs of the precursors of several deadly viruses ( $\mathrm{Hu}$ et al. 2015). The ongoing pandemic of acute respiratory syndrome originating in Wuhan, China in December 2019 was caused by SARS-CoV- 2 that shared $96 \%$ identity with a bat-borne coronavirus at the whole-genome level (Andersen et al. 2020, Zhou et al. 2020). Only a few bat viruses can spillover from animals to human through direct contact, which increases their epidemic potential (Hu et al. 2015, Zhou et al. 2020). However, bats provide important ecological roles such as pollination, pest control and seed dispersal that leads to natural forest growth ( $\mathrm{BCl} 2020)$. Ecologically and taxonomically bats form a diverse group accounting for roughly a fifth of world's mammalian diversity, with almost 1400 species now recognized (Burgin et al. 2018, Frick et al. 2019). Lamentably over a third of bat species assessed by the International Union for Conservation of Nature (IUCN) are considered threatened or data deficient, and more than half of the species have unknown or decreasing population trends (Frick et al. 2019). Moreover, there is a paucity of bat research in the regions of the world with the greatest bat diversity that impedes conservation (Frick et al. 2019). The Asian region boasts about 450 species of bats ( $\mathrm{BCl} 2020)$. Among the southeast Asian countries, Indonesia has the highest number of bats - 219 species ( $\mathrm{BCl} 2020$ ) and India represents about 125 species that is the highest among south Asian countries (Srinivasulu et al. 2010).

Bangladesh is positioned at the eastern end of the Indian subcontinent (Stanford 1991). This region forms a junction of two biogeographic realms- the Indo-Himalayas and Indo-China subregions that form a transitional zone for the flora and fauna of the subcontinent and that of Southeast Asia (Stanford 1991). However, chiropteran fauna in Bangladesh is poorly studied (Saha et al. 2015, 2017a). Khan (2001) reported a checklist of 31 species of bats in Bangladesh, whereas Molur et al. (2002) reported 34 species. Later, Sarker \& Sarker (2005) reported that 29 
species occurred in Bangladesh. While reviewing the existed documents of the country's chiropteran fauna, Srinivasulu \& Srinivasulu (2005) concluded that 38 species occurred in Bangladesh. After almost ten years, Khan (2015) updated the checklist and mentioned 33 species of bat found in the country. Finally, a total of 35 species of bats were reported in Bangladesh including eight newly recorded species (IUCN Bangladesh 2015). While three species were recently added to the country's inventory (Saha et al. 2017a, 2017b, Khan 2018, Mia et al. 2019). Several species namely, Lesser Mouse-tailed Bat Rhinopoma hardwickii, Little Nepalese Horseshoe Bat Rhinolophus subbaidius, Egyptian Freetailed Bat Tadaridaa egyptiaca, and Tail-less Leaf-nosed Bat Coelops frithii were included in the country checklist as the 'data deficient' species though the occurrence of these species are still doubtful and requires further review (IUCN Bangladesh 2015). Although several other species such as the Horseshoe Bat Rhinolophus pearsonii, Thick-eared Bat Eptesicus pachyotis, Papillose Woolly Bat Kerivoula papillosa, Savi's Pipistrelle Hypsugo savii and Harlequin Bat Scotomanes ornatus were reported to occur in the country but were not considered for status assessment due to a lack of confirmed records, voucher specimens or photographic evidence (IUCN Bangladesh 2015). Moreover, the Great Woolly Horseshoe Bat Rhinolophus luctus was evidently reported to occur in Bangladesh (Chowdhury 2013) but was not included in the checklist of IUCN Bangladesh (2015). Hence, it is clear that the bat fauna in Bangladesh is poorly understood with limited information on their distribution, status, and ecology (Molur et al. 2002, IUCN Bangladesh 2015). Here, we report the occurrence of Rhinolophus luctus in Northeast Bangladesh based on photographic evidence of a pair from Patharia Hill Reserve Forest.

Patharia Hill Reserve Forest $\left(\sim 60 \mathrm{~km}^{2}\right)$ is situated in the Moulvibazar district under Sylhet division in north-eastern Bangladesh (Rahman 2017). The geopolitical boundary between India and Bangladesh has divided the forest connectivity except for an Elephant (Elephas maximus) corridor. The area is hilly with numerous streams passing through the landscape. The forest is semi-evergreen dominated by bamboos (Bambusa spp.). Expansion of tea gardens, lemon gardens and other monoculture plantations has catalysed deforestation of natural forest cover (Ahmed et al. 2020). Illegal hunting for meat and live animal trading by local communities threatens many animals in the forest (Ahmed et al. 2020). Moreover, the forest is not wellexplored, and cataloguing of species diversity have been inadequate.

We conducted one-week field surveys in September of 2019 at Patharia Hill Reserve Forest to assess the globally endangered Western Hoolock Gibbon (Hoolock hoolock) population. On September 4, 2019, at 15:55h while surveying along the shoreline of a rocky stream, we opportunistically discovered a pair of horseshoe bats (Fig. 1) under the shade of a bamboo thicket $\left(24^{\circ} 32^{\prime} 43.86^{\prime \prime} \mathrm{N}\right.$, $\left.92^{\circ} 13^{\prime} 35.36^{\prime \prime} \mathrm{E}\right)$. The individuals were hanging approximately $8 \mathrm{~m}$ above the ground. We did not have permission or the necessary mist nets to capture and measure the specimens. Thus, we took high-resolution images using NIKON D3200 Camera with 55-300mm lens. The species was identified as Rhinolophus luctus following external morphological characters described by Csorba et al. (2003). This was based on diagnostic characters such as pronounced circular basal lappets (Fig. 1A); the tip of the sella (flat, lid-like structure at the centre of the nose) was pointed and angled forwards, reduced and rounded off connecting process; they had a well-developed lancet (triangular portion at the tip of the nose) with rounded off the tip (Fig. 1C); and the large horseshoe that covers the lips on all sides (Fig. 1B) (Csorba et al. 2003, Baniya et al. 2019).

The Family Rhinolophidae is represented globally by a single genus, Rhinolophus with 87 species in 15 species groups based on close morphological relationships (Csorba et al. 2003, Soisook et al. 2015). Rhinolophus luctus is listed under the trifoliatus group with 4 other species- $R$. beddomei, $R$. sedulus, $R$. formosae and $R$. trifoliatus (Csorba et al. 2003). External morphology of $R$. luctus is very similar to $R$. beddomei but separated by their size and geographic distribution (Menon 2014). R. luctus is larger than $R$. beddomei (Menon 2014). R. beddomei is distributed only in Southern India and Sri Lanka (Srinivasulu \& Srinivasulu 2019) whereas $R$. luctus has a widespread distribution in South Asia, southern China and South East Asia from sea level to an elevation of $1,600 \mathrm{~m}$ (Thong et al. 2019) (Fig. 2). R. luctus is larger than Rhinolophus sedulus (Baniya et al. 2019), and the latter species is distributed in the far southeast-Peninsular Malaysia, Indonesia, and Brunei (Hutson \& Kingston 2008). $R$. luctus can be further separated from $R$. trifoliatus by the non-yellowish colour of the dark nose leaf and ears (Csorba et al. 2003). $R$. formosae was once considered as a subspecies of $R$. luctus, due to its distinct morphology and endemism to Taiwan (Csorba et al. 2003), but it is now considered a separate species (Huang et al. 2019). All the members of the trifoliatus group have laterally projecting lappets at the base of the sella (Csorba et al. 2003, Baniya et al. 2019).

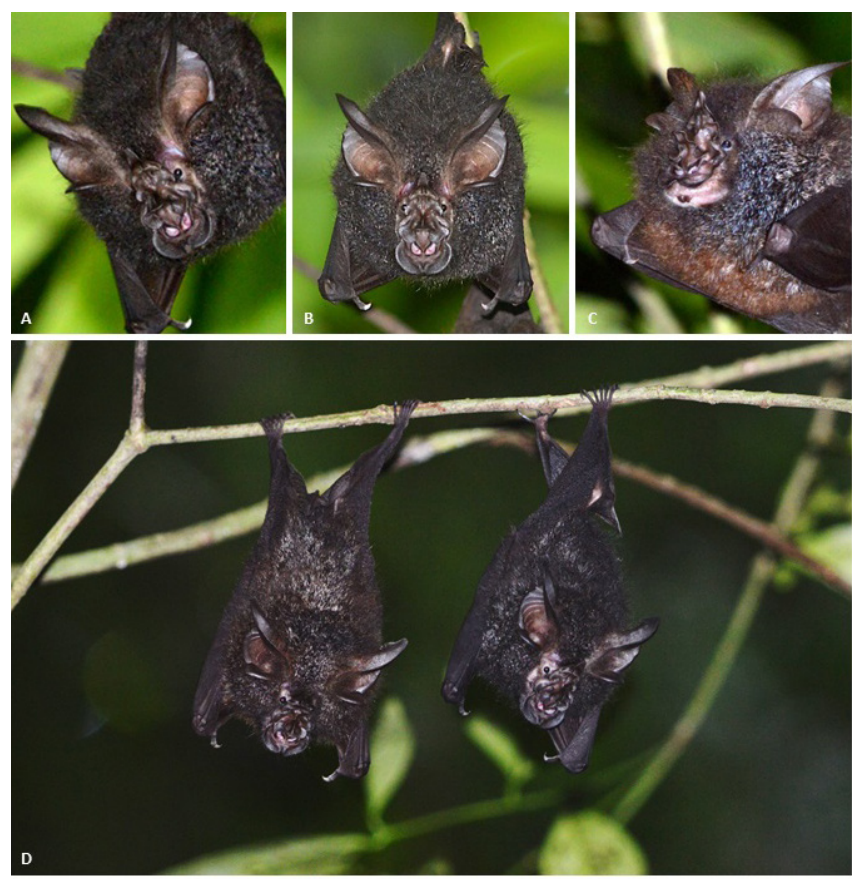

Fig. 1 - A) and B) Rhinolophus luctus with pronounced circular basal lappets and large Horseshoe, C) Tip of the sella pointed and angled forwards, reduced and rounded off connecting process, welldeveloped lancet with rounded off the tip, D) The $R$. luctus pair at Patharia Hill Reserve Forest, Bangladesh. 


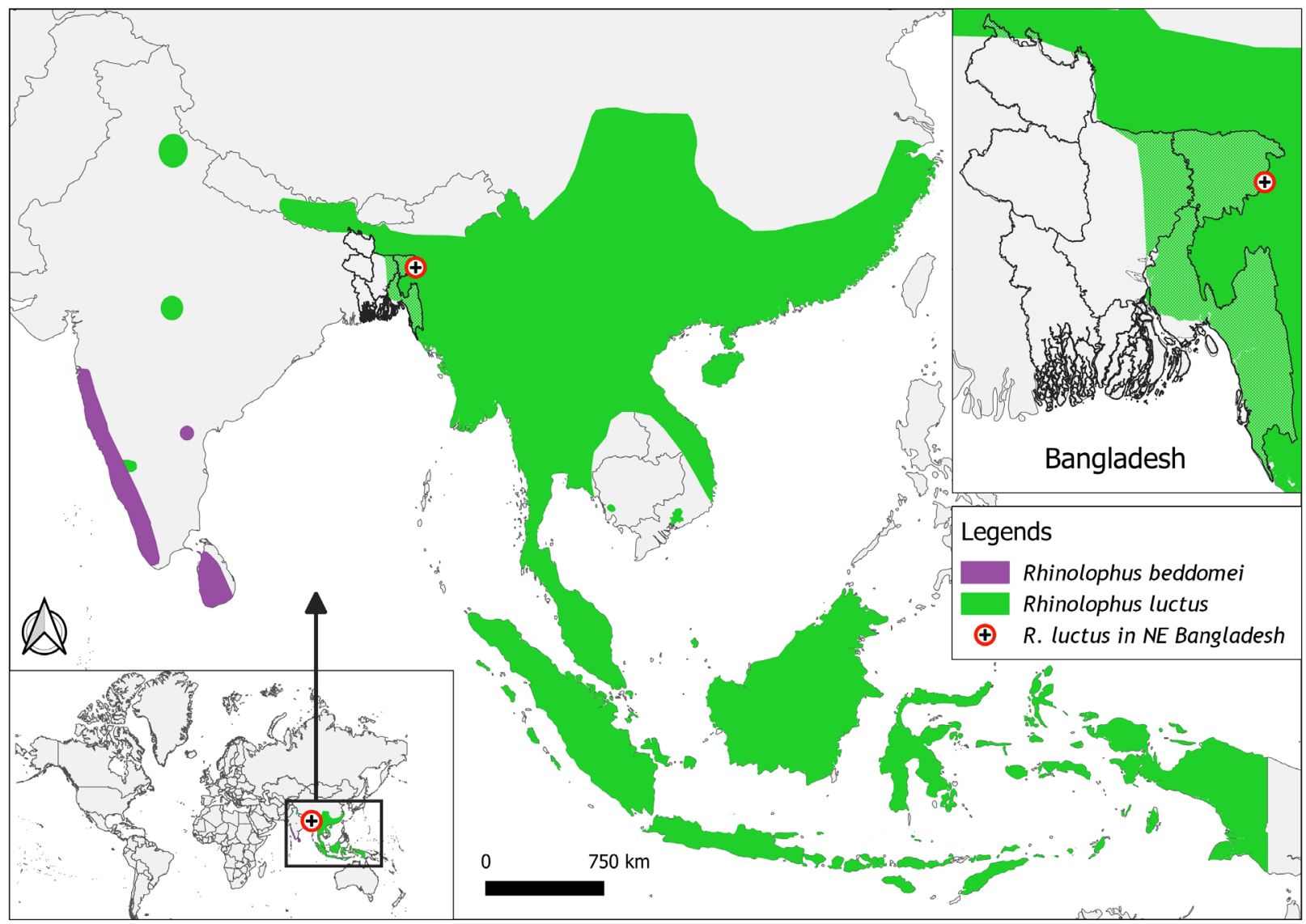

Fig. 2 - Global distribution of Rhinolophus luctus (Thong et al. 2019) and Rhinolophus beddomei (Srinivasulu \& Srinivasulu 2019) along with the R. luctus record in northeast Bangladesh. (Source: www.iucnredlist.org by following their terms and conditions for scientific publication only).

Although $R$. pearsonii of the pearsonii group is similar to the juvenile $R$. luctus, they lack basal circular lappets (Acharya et al. 2010).

The genus Rhinolophus is represented by 20 species in South Asia (Srinivasulu et al. 2010). Only five species ( $R$. affinis, $R$. pusillus, $R$. lepidus, $R$. subbadius and $R$. luctus) have been reported from Bangladesh including the unconfirmed occurrence of $R$. subbadius (Chowdhury 2013, Saha et al. 2017a, Khan 2018, IUCN Bangladesh 2015). Additionally, $R$. pearsonii was excluded in IUCN Bangladesh (2015) due to lack of sufficient data. The $R$. luctus was predicted to occur in Bangladesh based on its presence in north-eastern India and adjoining areas (Khan 2001). Chowdhury (2013) first confirmed the presence of R. luctus in Bangladesh based on the photographic evidences from Chittagong Hill Tracts. Despite the published record, IUCN Bangladesh (2015) did not include the species in the country checklist. Moreover, mentions of the presence of $R$. luctus in Bangladesh reported by Molur et al. (2002), Srinivasulu \& Srinivasulu (2005), Srinivasulu et al. (2010) and Thong et al. (2019) were referred to the prediction of Khan (2001). It was further mentioned that $R$. luctus is likely to present in the evergreen/mixed evergreen forests of the country but "no sight record" (Khan 2015, 2018). In fact, no other report had been found towards its confirmed occurrences in Bangladesh to date except an unpublished photographic evidence. So, the present record from Patharia Hill Reserve Forest is the first published report of $R$. luctus in northeast Bangladesh. The closest reported distributional record for the species is reported from the Indian side of Patharia Hill Reserve forest (Talukdar \& Choudhury 2017).

R. luctus is a forest-dwelling bat (Bates \& Harrison 1997), recorded roosting solitarily or in pairs in large caves, rocky outcrops, overhanging ledges, and large hollow trees (Molur et al. 2002, Baniya et al. 2019). The populations of many species, mostly forest dwellers, are in steep decline in Bangladesh having faced habitat destruction in recent decades (IUCN Bangladesh 2015). However, R. luctus is considered less sensitive to disturbance than other forestdwelling bats, for example in Nepal it has shown to be unaffected by intense noise pollution (Baniya et al. 2019). Similarly, our sighting was also in a disturbed and logged mixed evergreen hill forest where natural forest cover is being substituted gradually by agricultural conversion to monoculture plantations. Globally R. luctus is listed as 'Least Concern' species but its ecology is poorly known (Thong et al. 2019). Hence, the species might be threatened by deforestation due to logging, agricultural development, plantations, and forest fires, which affect both prime foraging habitat as well as roosting habitats (Thong et al. 2019). Therefore, further research is required on the ecology of the species, including density, habitat preference and diet in Bangladesh. Until then, the species can be considered as 'Data Deficient' in Bangladesh according to the guideline of IUCN Bangladesh (2015).

Although the forest cover of Patharia Hill Reserve Forest is degrading rapidly, it is still considered one of the last 
wildernesses in Bangladesh that support many threatened wildlife species, including the globally 'Endangered' Phayre's Langur Trachypithecus phayrei (Ahmed et al. 2020), Hoolock Gibbon Hoolock hoolock (Muzaffar et al. 2007) and Asiatic Elephant Elephus maximus (Talukdar \& Choudhury 2017). Several pockets of natural vegetation within the forest reserve remain untouched by anthropogenic degradation and the forest adjacent to the India-Bangladesh border remains free from logging. Ahmed et al. (2020) recommended upgrading the protection status of the forest to conserve its diverse and threatened fauna. Thus, immediate investigations and assessment of the faunal diversity and their status in Patharia Hill Reserve Forest should be initiated. Particularly, an inventory on the bats in the rapidly degrading Patharia forest is pivotal to initiate conservation measures for these species. Moreover, the habitats bats occupy in the country are already under a myriad of anthropogenic threats. So, an urgent holistic approach is recommended to prepare an inventory and distributional data of the bat fauna in Bangladesh to formulate an action plan for their sustainable conservation.

\section{ACKNOWLEDGEMENTS}

We thank Dr Alice C. Hughes for helping in species identification, valuable suggestions, and comments on the early draft of the manuscript. Mr Rohit Chakravarty and Mr Krizler C. Tanalgo gave important suggestions. Bangladesh Forest Department, Department of Zoology of Jagannath University and Department of Biology of United Arab Emirates University facilitated our project. US Fish and Wildlife Service funded the project (ID: F19AP00130). $1^{\text {st }}$ author acknowledges The IDEA WILD, USA for supporting a few of his field equipment. We are grateful to Dr Claire Wordley, two anonymous reviewers and editor for their useful comments and corrections that improved the manuscript. We also thank Mr. Samiul Mohsanin for supporting with literatures from his personal collections.

\section{REFERENCES}

ACHARYA, P. R., ADHIKARI, H., DAHAL, S., THAPA, A. \& THAPA, S. (2010). Bats of Nepal: a field guide. ed.: Small mammals conservation and research foundation. New Baneshwor, Kathmandu, Nepal, 116 pp.

AHMED, T., HASAN S., NATH, S. \& BISWAS, S. (2020, 8-10 February). Population status of Phayre's langur in north-eastern forests of Bangladesh. 7th Asian Primate Symposium and 1st International Conference on HumanPrimate Interface, Guwahati, Assam, India.

ANDERSEN, K. G., RAMBAUT, A., LIPKIN, W. I., HOLMES, E. C. \& GARRY, R. F. (2020). The proximal origin of SARSCoV-2. Nat. Med., 26: 450-452. https://doi.org/10.1038/ s41591-020-0820-9

BANIYA, S., SHARMA, B., KHANAL, C., RAUT, N. \& ACHARYA, P. R. (2019). Record of Great Woolly Horseshoe Bat (Rhinolophus luctus, Temmick 1834) in Western Nepal. Journal of Bat Research \& Conservation, 12(1): 27-32. https://doi.org/10.14709/BarbJ.12.1.2019.04
BAT CONSERVATION INTERNATIONAL (BCI). (2020, April 4). Bat Conservation International, USA. http://www. batcon.org

BATES, P. J. J. \& HARRISON, D. L. (1997). Bats of the Indian Subcontinent. ed.: Harrison Zoological Museum Publications. Sevenoaks, Kent, United Kingdom, 258 pp.

BORRIES, C. \& KOENIG, A. (2014). Opportunistic sampling of felid sightings can yield estimates of relative abundance. Cat News, 61: 34-36.

BURGIN, C. J., COLELLA, J. P., KAHN, P. L. \& UPHAM, N. S. (2018). How many species of mammals are there? Journal of Mammalogy, 99(1): 1-14. https://doi.org/10.1093/ jmammal/gyx147

CSORBA, G., UJHELYI, P. \& THOMAS, N. (2003). Horseshoe bats of the world (Chiroptera: Rhinolophidae). ed.: Alana Books. Shropshire, United Kingdom, 160 pp.

FRICK, W. F., KINGSTON, T. \& FLANDERS, J. (2019). A review of the major threats and challenges to global bat conservation. Ann. N.Y. Acad. Sci. https://doi. org/10.1111/nyas.14045

HU, B., GE, X., WANG, L. \& SHI, Z. (2015). Bat origin of human coronaviruses. Virol. J., 12: 221. https://doi.org/10.1186/ s12985-015-0422-1

HUANG, J. C. -C., LEE, Y., HO, Y., CHOU, C. \& CHENG, H. -C. (2019). Rhinolophus formosae. The IUCN Red List of Threatened Species 2019: e.T136644A21989870. Downloaded: 26 April 2020. https://doi.org/10.2305/ IUCN.UK.2019-3.RLTS.T136644A21989870.en

HUTSON, A. M. \& KINGSTON, T. (2008). Rhinolophus sedulus. The IUCN Red List of Threatened Species 2008: e.T19565A8978590. Downloaded: 27 September 2019. https://doi.org/10.2305/IUCN.UK.2008.RLTS. T19565A8978590.en

IUCN BANGLADESH. (2015). Red List of Bangladesh. Volume 2: Mammals. ed.: IUCN Bangladesh Country Office. Dhaka, Bangladesh, 232 pp.

KHAN, M. A. R. (2001). Status and distribution of bats in Bangladesh with notes on their ecology. Zoos' Print Journal, 16(5): 479-483. https://doi.org/10.11609/JoTT. ZPJ.16.5.479-83

KHAN, M. A. R. (2015). Wildlife of Bangladesh: checklist and guide. ed.: Chayabithi. Dhaka, Bangladesh , 568 pp.

KHAN, M. M. H. (2018). Photographic guide to the wildlife of Bangladesh. ed.: Arannayk Foundation. Dhaka, Bangladesh, 488 pp.

MENON, V. (2014). Indian mammals: a field guide. ed.: Hachette India. Gurgaon, India, 528 pp. 
MIA, M., SAHA, A., FEEROZ, M. M. \& HASAN, M. K. (2019). Greater long-nosed fruit batMacroglossus sobrinus: a new distribution record in Bangladesh. Journal of the Bombay Natural History Society (JBNHS), 116: 72-73. https://doi. org/10.17087/jbnhs\%2F2019\%2Fv116\%2F107425

MOLUR, S., MARIMUTHU, G., SRINIVASULU, C., MISTRY, S., HUTSON, A. M., BATES, P. J. J., WALKER, S., PRIYA, K. P. \& PRIYA, A. R. B. (2002). Status of South Asian Chiroptera: Conservation Assessment and Management Plan (C.A.M.P.) Workshop Report, 2002. ed.: Zoo Outreach Organisation, CBSG South Asia and WILD. Coimbatore, Tamil Nadu, India, 320 pp.

MORRISON, M. L., BLOCK, W. M., STRICKLAND, M. D., COLLIER, B. A. \& PETERSON, M. J. (2008). Wildlife study design. $2^{\text {nd }}$ edition. ed.: Springer-Verlag New York. New York, United States of America, 386 pp. https://doi. org/10.1007/978-0-387-75528-1

MUZAFFAR, S. B., ISLAM, M. A., FEEROZ, M. M., KABIR, M., BEGUM, S., MAHMUD, M. S., CHAKMA, S. \& HASAN, M. K. (2007). Habitat characteristics of the endangered Hoolock gibbons of Bangladesh: the role of plant species richness. Biotropica, 39: 539-545. https://doi. org/10.1111/j.1744-7429.2007.00298.x

OKES, N. C. \& O'RIAIN, M. J. (2019). Can opportunistic citizen sightings assist in the monitoring of an elusive, crepuscular mammal in an urban environment? Urban Ecosystems, 22: 483-492. https://doi.org/10.1007/ s11252-019-0829-3

RAHMAN, H. A. (2017). Mammal biodiversity in the northeast forests, and the distribution of fishing cats in Bangladesh. University of Delaware. Newark, Delaware, USA.

SAHA, A., HASAN, M. K. \& FEEROZ, M. M. (2015). Diversity and morphometry of chiropteran fauna in Jahangirnagar University campus, Savar, Dhaka, Bangladesh. Bangladesh Journal of Zooogy, 43(2): 201-212. https:// doi.org/10.3329/bjz.v43i2.27392

SAHA, A., FEEROZ, M. M. \& HASAN, M. K. (2017a). Recent record of Javan pipistrelle (Pipistrellus javanicus, Gray 1838) from Chittagong Hill Tracts (CHT), Bangladesh. Journal of Bat Research \& Conservation, 10(1). https:// doi.org/10.14709/BarbJ.10.1.2017.05
SAHA, A., FEEROZ, M. M. \& HASAN, M. K. (2017b). Cryptic Rhinolophus pusillus Temminck, 1834 (Chiroptera, Rhinolophidae): a new distribution record from the Chittagong Hill Tracts, Bangladesh. Check List, 13 (4): 293-296. https://doi.org/10.15560/13.4.293

SARKER, S. U. \& SARKER, N. J. (2005). Bats of Bangladesh with notes of their status, distribution and habitat. Bat Net-CCINSA Newsletter, 6(1): 19-20.

SOISOOK, P., STRUEBIG, M. J., NOERFAHMY, S., BERNARD, H., MARYANTO, I., CHEN, S. -F., ROSSITER, S. J., KUO, H. -C., DESHPANDE, K., BATES, P. J. J. et al. (2015). Description of a new species of the Rhinolophus trifoliatus - group (Chiroptera: Rhinolophidae) from Southeast Asia. Acta Chiropterologica, 17(1): 21-36. https://doi.org/10.3161/ 15081109ACC2015.17.1.002

SRINIVASULU, B. \& SRINIVASULU, C. (2019). Rhinolophus beddomei. The IUCN Red List of Threatened Species 2019: e.T40023A22061859.Downloaded: 23 April 2020. https://doi.org/10.2305/IUCN.UK.2019-3.RLTS. T40023A22061859.en

SRINIVASULU, C. \& SRINIVASULU, B. (2005). A review of chiropteran diversity of Bangladesh. BAT NET-CCINSA Newsletter, 6(2): 6-11.

SRINIVASULU, C., RACEY, P. A. \& MISTRY, S. (2010). A key to the bats (Mammalia: Chiroptera) of South Asia. Journal of Threatened Taxa, 2(7): 1001-1076. https://doi. org/10.11609/JoTT.o2352.1001-76

TALUKDAR, N. R. \& CHOUDHURY, P. (2017). Conserving wildlife wealth of Patharia Hills Reserve Forest, Assam, India: a critical analysis. Global Ecology and Conservation, 10: 126-138. https://doi.org/10.1016/j.gecco.2017.02.002

THONG, V. D., THANH, H. T., SOISOOK, P. \& CSORBA, G. (2019). Rhinolophus luctus. The IUCN Red List of Threatened Species 2019: e.T19548A21977086. Downloaded: 23 April 2020. https://doi.org/10.2305/IUCN.UK.2019-3. RLTS.T19548A21977086.en

ZHOU, P., YANG, X. -L., WANG, X. -G., HU, B., ZHANG, L., ZHANG, W., SI, H. -R., ZHU, Y., LI, B. et al. (2020). A pneumonia outbreak associated with a new coronavirus of probable bat origin. Nature, 579: 270-279. https://doi. org/10.1038/s41586-020-2012-7 